\title{
Regionalism at all costs \\ Nallo Mazzocchi Alemanni and the Bradano Valley Land Reclamation Project, 1955.
}

\author{
Filippo De Dominicis ${ }^{1,1}$ \\ ${ }^{1}$ Independent scholar, Rome, Italy.
}

\begin{abstract}
Between 1950 and 1956, one fifth of the Italian landscape was profoundly reshaped. According to the first ten-year plan issued by the Cassa per il Mezzogiorno, 51 aqueducts and around 3,000 km of roads would provide the necessary infrastructure to rehouse millions of farmers, while 139 new settlements and 46,450 isolated houses would result from the new subdivision of land. Besides the national funds, newly established local authorities were entrusted with the handling of all technical aspects concerning land reclamation and resettlement. Far from being the mere result of political agreements, such an impressive and multi-faceted reform process stood at the intersection of cultural debates, national ambitions and foreign ascendancies that sought substantial alternatives to modernization and urbanization. This paper highlights an off-radar case study, with the aim of presenting and understanding some of the aspects featuring in the Italian discourse on rural planning. It deals with the intervention of the Bradano Valley Land Reclamation Authority and its main consultant, Nallo Mazzocchi Alemanni, and frames their efforts in the larger and multifaceted postwar Lucanian experience. Inscribed in the contemporary debate on regionalism and planning, the technical stance of Mazzocchi Alemanni would provide the foundation upon which to unfold the interweaving of contradictory ideologies deployed by intellectuals and activists seeking to uplift the Italian Mezzogiorno.
\end{abstract}

\section{The Italian path to regionalism}

In the aftermath of World War II, reconstruction in Italy was the opportunity to go beyond the idea of the city as an artefact, limited in its own extension and differing from the surrounding rural and productive areas. According to Adalberto Libera ${ }^{2}$, one of the most renowned Italian professionals of the time, the new object of focus was to be the region as a whole [1: 104]. Such a broad perspective - epitomized by the position of Libera was common to most architects and planners involved in the discourse on national reconstruction. Pushed by the urgency in deciding how best to apply the 1942 urban

\footnotetext{
${ }^{1}$ Corresponding author: filodedominicis@gmail.com

2 1903-1963. Italian architect and planner. He was one of the most active professionals before and after World War II. For his theory of regionalism and dispersal, see [1].
} 
planning act, Italian intellectuals and technical elites had spent years debating which model to follow, frequently turning abroad in search of the best references and a break with the Fascist past [2].

The main issue consisted in the redefinition of the tenets of the planning discipline, understanding its scope as well as the way in which it encompassed the widest range of design scales [3]. Journals, publications and institutions steered the debate toward an open and multidisciplinary discourse, which, apart from constituting a moral stance, was also intended on broadening the scope of the discipline to the largest possible extent $^{3}$. Within that framework, rural and regional planning emerged as one of the most relevant terrains where economists, planners and architects engaged in their battles on reconstruction and planning. In a short while, the region became the paradigm around which the ideological and technical debates grew, contrasting with geographical and administrative principles and giving voice to new forms of human associations. Models like greenbelts, garden cities and neighbourhood units were widely propagandized with the aim of overtaking a restrictive administrative logic. On the other hand, such models emerged as the key concepts stressing a more comprehensive approach to planning ${ }^{4}$.

The idea of the region, as the earliest result of the work on the boundaries of the planning discipline, functioned both in practical and ideological terms. Besides the concerns regarding rational and organic spatial development, the gradual inclusion of rural areas in the planning process sought to redefine the wider economic and political frame where the planning itself had to be inscribed. While embracing the countryside, a regional perspective would ensure the protection of human communities against urban encroachment and speculative development, as well as pilot a new form of economic planning [4]. In other words, the regional frame, along with its contested and multifaceted interpretations, became the instrument used to steer a new model of largescale development, often inspired by previous transatlantic experiences like the Tennessee Valley Authority and the Resettlement Administration [5].

\section{Regionalism, ruralism and ideology}

Against this background, the profound structural weakness that characterized the heart of Southern Italy proved to be fertile ground for those yearning for a new direction in planning. Furthermore, after Levi's Cristo si è fermato a Eboli ${ }^{5}$, the Italian Mezzogiorno stood at the crossroads of national and foreign interests [6]. Indeed, the places depicted by Levi benefitted from a large political audience, which played a substantial role in backing and driving one of the largest and most complex planning operations to ever be undertaken in modern Italy. Since the end of World War II, the south of the country witnessed a dramatic interplay of a multitude of actors: for ten years, politicians, technicians and associated intellectuals, from Italy and abroad, put forward various proposals aimed at modernizing and lifting the region out of backwardness [7], each

\footnotetext{
${ }^{3}$ See, for instance, the first issues of Metron and Comunità, in which prominent personalities like Bruno Zevi, Luigi Piccinato, Mario Ridolfi and Ludovico Quaroni were involved.

${ }^{4}$ The first issue of Metron, in August 1945, opened with an essay by Lewis Mumford on the garden city and its reception in the United States.

5 1902-1975. Italian writer and painter, he was one of most important anti-Fascist intellectuals. His most famous and important work, Cristo si è fermato a Eboli, sprang from his exile in Lucania (first in Grassano and then in Aliano) between 1935 and 1936.
} 
carrying out his own personal plan of development, often with little to no coordination between them ${ }^{6}$.

At the same time, the Italian countryside reflected the continuity of an uncorrupted and anti-capitalist ideology, an alternative and organic vision to be handed down to future generations. The small town of Matera - which in 1947 housed less than 30,000 inhabitants, including 17,000 people living in the Sassi neighborhood - emerged as the paradigmatic case [8] of that ambiguity ${ }^{7}$. According to Manfredo Tafuri ${ }^{8}$, Levi's Matera was soon considered a potential "autonomous rural community" [9: 35-41] in contrast to the political and social establishment, a sort of closed ensemble in which social, economic and environmental values had been preserved from the passing of time [9]. While the political and technical elite deemed the horrific scenario of the Sassi as a source of national shame ${ }^{9}$, to be remedied by technical and rational solutions [10], the Italian intelligentsia - bolstered by the studies of American social scientists - saw in the primordial balance of the Sassi a model to follow. The thousand-year layering of practices and the consequent mechanisms of human association embodied a positive and pure narrative worthy of being preserved and transmitted ${ }^{10}$.

In that sense, Matera and its cave dwellings epitomized a regional model in which the urban and the rural life were intimately connected: in order to work their land, indeed, most of the people inhabiting the Sassi were forced to undertake an eighthour round trip each day. For Manlio Rossi Doria ${ }^{11}$, the true essence - and richness - of rural life resided precisely in that back and forth movement. It was the only possibility that farmers had of keeping their lives connected to the larger community. In the words of Riccardo Musatti ${ }^{12}$, the large communitarian neighborhood was key to the possibility of rural workers achieving a minimum degree of social stability [11]. The rhetoric of such an ideological narrative clashed with the imperative to improve the living condition of those inhabiting the Sassi, fully revealing the contradictions in the thinking of the Italian intelligentsia.

Although advocating the primacy of rural values, intellectuals like Rossi Doria and Musatti felt the need to remedy the impressive overcrowding of the rural towns in the Italian Mezzogiorno. According to them, the only way of pursuing an organic regional development was through the reform of the ancient practice of land distribution and ownership. Such a practice had, in fact, been one of the underlying causes leading to

\footnotetext{
${ }^{6}$ According to data provided by the Cassa del Mezzogiorno, a state-sponsored authority which monitored public works in the South of Italy, 446,000 hectares of land were subject to reclamation. The first decennial plan following the 1950 Land Reform Act involved an enormous process of relocation that included the construction of 163 rural villages and over 45,000 isolated houses [7]. ${ }^{7}$ The first and most comprehensive monograph on Matera after the end of WWII is Toxey [8].

8 1935-1994. Italian architectural historian. He taught in Rome, where he was assistant of Ludovico Quaroni, and Venice, where he served as the director of the Department of Architectural History at the Istituto Universitario di Architettura di Venezia.

${ }^{9}$ Palmiro Togliatti and Umberto Tupini, respectively head of the Italian Communist Party and Minister of the Public Works, visited the town of Matera before the 1948 elections, between March and April [10].

${ }_{11}^{10}$ Tafuri quoted the interpretation of Levi provided by Alberto Asor Rosa [9: 36-37].

11 1905-1988. Italian agrarian economist and militant of the Communist Party during the Fascist period. From 1939 to 1943, Manlio Rossi Doria was exiled in Lucania. In 1944, he began teaching in Naples where his political engagement intensified while his professional profile grew.

12 1920-1965. Italian architect and planner. As one of the most influential members of the Movimento di Comunità, founded by Adriano Olivetti, Riccardo Musatti served as director of Olivetti's regional planning activities since 1949. Moreover, he was among the editors of Italia Socialista, Metron (with Bruno Zevi) and Zodiac.
} 
the founding of the community neighbourhood, but also constituted a major obstacle to the processes of resettlement and dispersal. Against this controversial and deeply ideological background, there were very few who succeeded in looking at regional planning as an opportunity for modernization and development.

\section{Nallo Mazzocchi Alemanni and the organic perspective}

As the site where many controversial aspects converged, Matera and its countryside had started drawing the attention of Italian and US officers and activists since the mid-1940s [10]. Following the 1948 elections, the Economic Cooperation Administration (ECA) - a US authority entrusted with the application of the European Reconstruction Program (ERP) - commissioned professor Nallo Mazzocchi Alemanni to draw up a preliminary plan for the recovery of the Sassi. Nallo Mazzocchi Alemanni ${ }^{13}$, a consultant engineer for the Bradano Valley Reclamation Authority and friend of Manlio Rossi Doria, held extensive experience in rural planning and development, which he had gained in Italy and abroad.

In January 1950, in collaboration with the engineer Enzo Calia, Mazzocchi Alemanni issued a first hypothesis ${ }^{14}$, which assumed that the social, cultural, economic and sanitary problems affecting the Sassi were intimately related to a larger agrarian transformation [13]. According to Mazzocchi Alemanni's "organic" perspective, the Sassi had to be evacuated primarily for "moral, social and hygienic reasons" 15 . Cave dwellers were to be resettled in three rural villages to be built along the main axes leading to the countryside ${ }^{16}$ as well as in two large low-income neighbourhoods, located on the outskirts of the city ${ }^{17}$. Mazzocchi Alemanni was certain that the establishment of a dispersed layout was the essential precondition for any type of land reform [14-15]. On the other hand, he had already studied the post-war theory of dispersal when, in 1946, he was commissioned to undertake the rural planning of the Tavoliere, a plain in Northern Apulia [16]. The Materan case was even more appropriate than the Apulian project, given the presumed evacuation of the Sassi and the consequent necessity of resettling its former inhabitants. For the first time, someone had posited the question of the Sassi recovery in terms of a mass evacuation.

As a technician, Mazzocchi harboured no nostalgia for the values that would inevitably be lost. On the contrary, his aim was to break up a layout consisting of overpopulated and spaced out settlements. His appraisal was merely technical and aspired to maximum efficiency. Considering the daily commute from the town to the farmland a complete waste of time, Mazzocchi deemed it necessary to spread settlements over a broader sector, thus situating the problem within the framework of large-scale planning.

13 1889-1967. Italian engineer and agrarian economist. During Fascism, Nallo Mazzocchi Alemanni had been working in the African continent (Somalia and Angola). Upon his return to Italy, he was involved in several land reclamation projects (Sicily, Umbria, Latium, Apulia and eventually Lucania).

${ }^{14}$ The report was followed by the Piano generale di bonifica del territorio comunale di Matera. A first sketch was published in Piccinato, 1955 [12].

${ }^{15}$ Mazzocchi Alemanni's report declared $72 \%$ of the houses in the Sassi uninhabitable.

${ }^{16}$ Borgo Timmari, Borgo Venusio and Borgo Torre Spagnola were located 10-12 km from the Sassi.

${ }^{17}$ In the Piccianello and Cappuccini areas. 
Adriano Olivetti ${ }^{18}$ was one of the first to embrace Mazzocchi Alemanni's proposal ${ }^{19}$; adding to his technical rationale a decisively communitarian imprint ${ }^{20}$. In January 1949 , well before the plan was published, he had endorsed the reformist thinking of Mazzocchi Alemanni in an article titled Per le comunità rurali del Mezzogiorno. In the short piece, Olivetti praised Mazzocchi Alemanni's strategy of dispersal, linking the development of Southern Italy to the process of planning established by Roosevelt's New Deal and the Tennessee Valley Authority Act [4-16-19]. However, Olivetti partially misrepresented Mazzocchi Alemanni's position, emphasizing his tenuous spiritual stance against the much more relevant technical aspects of his plan [17]. On the other hand, technical and practical roots had featured in the Lucanian vision of Mazzocchi Alemanni since 1948, when he started his consultancy for the Bradano Valley Reclamation Authority with a small project in the municipality of Irsina [20]. The project for the demanio Matinelle anticipated the themes and topics that would later distinguish the regional scheme for Matera and its surroundings. In the written report, Mazzocchi Alemanni made explicit reference to the need for colonizing land with some "demographic centres", a model of settlement that, by encouraging a population decrease in existing towns, would permit development beyond the logic of Agro Pontino's auxiliary centres and isolated houses ${ }^{21}$.

\section{The communitarian contradictions}

In 1951, in partnership with the United Nations Relief and Rehabilitation Administration (UNRRA), Olivetti launched the Commissione per lo Studio della città e dell'agro di Matera. The board, which brought together ethnologists, sociologists, psychologists, social engineers and architects ${ }^{22}$, was constituted to research and develop each of the key factors shaping the Materan case. Meanwhile, UNRRA had decided to support the construction of the first rural village, La Martella [18], in the terms envisaged by the regional plan of Mazzocchi Alemanni and the Bradano Valley Reclamation Authority ${ }^{23}$.

\footnotetext{
${ }^{18} 1901$-1960. Italian engineer and industrialist. Adriano Olivetti was director of the Società Olivetti from 1932, after having obtained a master's degree in chemical engineering at the Politecnico di Torino. In 1937, he was the main promoter of the Piano Regolatore della Valle d'Aosta, perhaps the first regional planning experience in Italy. In the pre-war period and before his eventual departure to Switzerland, he was a strong opponent of the Fascist regime. Back in Italy, he founded the Movimento di Comunità in 1948. He was the director of the Istituto Nazionale di Urbanistica (INU), as well as the president of the first United Nation Relief and Rehabilitation Administration (UNRRA) from 1951.

${ }^{19}$ Likely, they were in touch thanks to Riccardo Musatti, editor in chief of Italia Socialista (in which Mazzocchi Alemanni collaborated) as well as an early protagonist of the Movimento di Comunità. In September 1949, both Olivetti and Mazzocchi Alemanni were in Matera with Riccardo Musatti, bringing the head of the ECA mission to visit the Sassi. See [17].

${ }^{20}$ According to Ludovico Quaroni - a prominent architect, close to Olivetti, as well as the author of La Martella, the only rural village actually built. Olivetti and Mazzocchi Alemanni worked together on the 1950 plan. See [18].

${ }^{21}$ Mazzocchi Alemanni highlighted that isolated houses and auxiliary centres were appropriate for large-scale reclaiming such as that which had been carried out in the Pontine Marshes. In fact, the reform of larger estates in Southern Italy required a different solution. Moreover, auxiliary centres were also conceived to minimize the concentration of people. See [20].

${ }^{22}$ G. Friedmann, G. Isnardi, E. Bracco, F. Nitti, T. Tentori, F. Gorio, L. Quaroni, R. Mazzarone, L. De Rita, G. Orlando, G. Marselli and R. Innocenti, coordinated by G.B. Martoglio. The Commissione published only three of the nine volumes originally prepared.

${ }^{23}$ La Martella village (L. Quaroni, F. Gorio, L. Agati and M. Valori) has been widely studied. For a first reference, see [2-9].
} 
It was understood that the model proposed by Mazzocchi Alemanni was ideologically borrowed by Olivetti and his Movimento to spread their tactics over the Materan lands.

Accordingly, the aims and actions of the Commissione proved to be highly controversial from the beginning. As highlighted in Tafuri's reading of De Rita and Musatti - two of the experts involved in the Commissione - the communitarian values of the Sassi, considered by the intellectuals as the base upon which to build a new, cooperative region, were nothing more than historical remains [9]. By then, forms of human association like the vicinato had lost their significance, having been detached from the urban fabric they had historically contributed to shaping. The ideological position revealed its own ambiguity when, turning to nostalgia, it intended to project the past onto an organic and future scenario. Consequently, the same notion of the region as conceived by Riccardo Musatti, an operating platform inscribed by an act of common living, lost its forward-thinking power. Seeking "vague historical traces", it turned away from its original and revolutionary purpose, instead turning back to a conservative and reactionary position [9-11]. According to Tafuri, the nostalgic tension embedded in the communitarian vicinato concealed a twofold purpose: the importance of the control and maintenance of underdevelopment as a status quo, and, the consequent impossibility for rural workers to partake from any sort of urban integration.

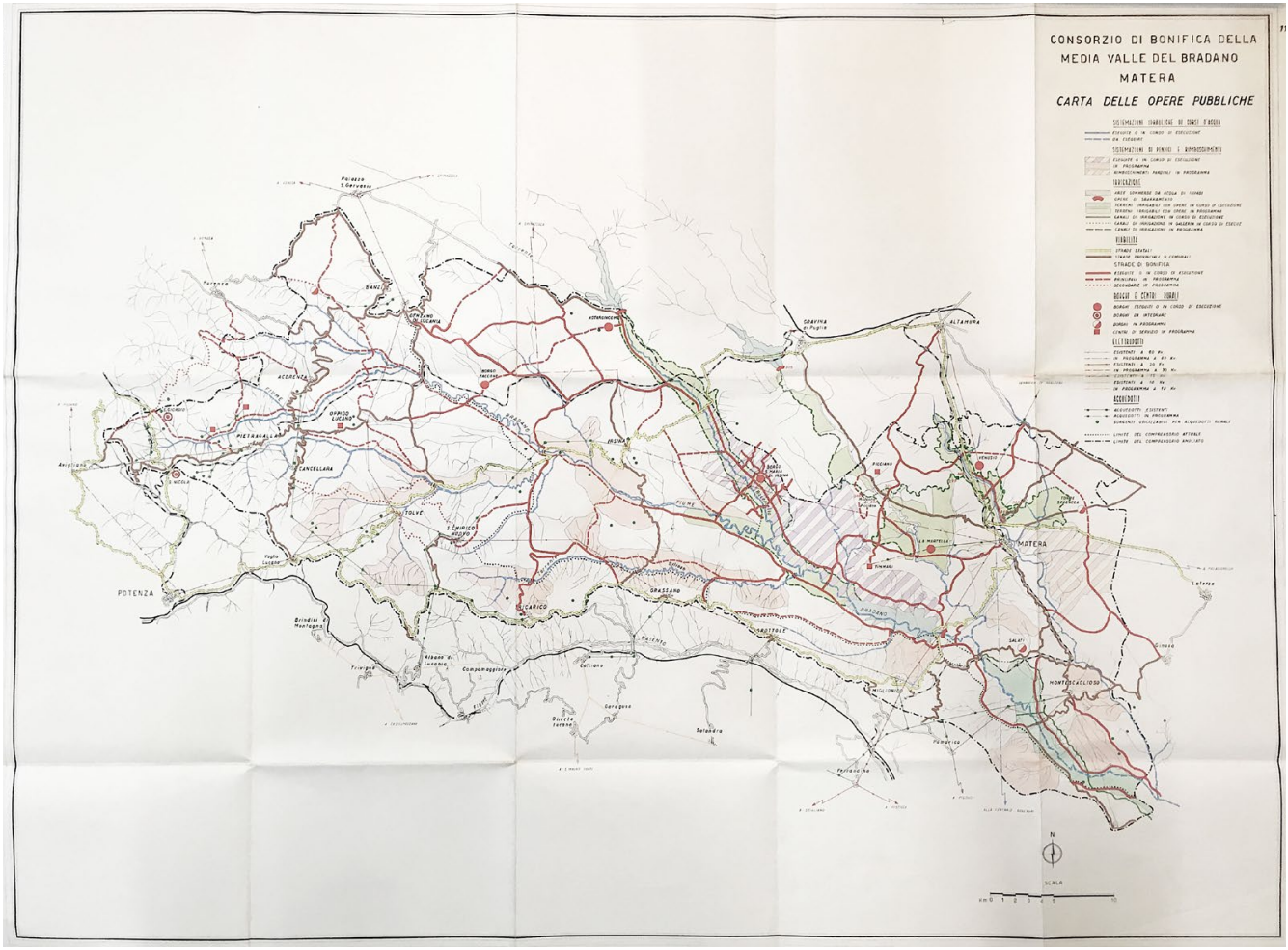

Fig. 1. Nallo Mazzocchi Alemanni. Public works in the Land Reclamation Plan for the Bradano Valley. Source: Courtesy of ANIMI, Archivio Nallo Mazzocchi Alemanni.

\section{The regional vision for the Bradano Valley}

The Commissione did not seek any coordination with the various institutions and authorities working toward the improvement of the region. However, the situation had 
evolved. The first rural settlement designed by Quaroni and others, which would serve as a communitarian model, met with the resistance of the Ente Riforma Puglia $e$ Lucania, the local authority created in 1952 to apply the 1950 land reform act [9]. In 1951, the Italian government ratified the proposal of Nallo Mazzocchi Alemanni [21], establishing by law the Sassi evacuation ${ }^{24}$. At the same time, Mazzocchi Alemanni had already started preparing a larger plan for the Bradano Valley, while Luigi Piccinato was tasked with drafting a municipal masterplan and the design for a second rural village, Venusio [12]. In 1953, the Istituto Nazionale di Urbanistica (INU), headed by Olivetti, requested that Italian architects and planners elaborate regional plans according to administrative subdivisions, thus de facto denying the assumptions of Riccardo Musatti [11].

The long report written by Ludovico Quaroni, one of the authors of the Lucanian Regional Preliminary $\mathrm{Plan}^{25}$, revealed the entanglement of political and cultural stances. Despite being part of the Commissione, Quaroni was lucid enough to sense the paradox inherent in the communitarian vision: pushing for development by safeguarding the existing balance meant not understanding that the lack of development resided precisely in the maintenance of that balance. Against the controversial challenge between reformist ambitions and reactionary tendencies, Quaroni directed his praise at the land reclamation authorities, the single entity actually concerned in long-term and large-scale modern development [22].

In 1955, Nallo Mazzocchi Alemanni published the Land Reclamation Plan for the Bradano Valley [23]. Relying on over 700 pages of data, Mazzocchi Alemanni extended the scale of intervention beyond administrative borders, eventually encompassing all questions related to the reform of land distribution, property, irrigation and settlement in the most organic and comprehensive manner. The Bradano Valley plan achieved the aim of regional planning starting from the same premises that had featured the 1949 Sassi recovery plan, in which urban, rural, social and cultural aspects had merged into a larger, organic portrait [13]. Inscribed in an overall perspective of development, the plan envisaged a broad spectrum of public and private interventions ranging from roads to reforestation, from aqueducts to resettlement. Each operation was rooted in a large and exhaustive historical background, a sort of neutral platform for the justification of continuities and ruptures created by the planning process. Indeed, nostalgic ideologies were at last put aside for the sake of a technically-oriented and appropriated vision that found in dispersal and infrastructural networking its key aspects.

For Mazzocchi Alemanni, the entire surface of the valley had to be inhabited in a rational manner following a complex interweaving of logics that differed substantially according to their field of application. Within that framework, these various rationales would also encourage the cooperation of institutional bodies and authorities which, in the perspective of Mazzocchi Alemanni, were the UNRRA, Ente Riforma, INU, as well as the many municipalities included. Such entities would be allowed to work together on the plan's multifaceted structure, overtaking the astonishing pulverization of tasks recorded by Quaroni at the INU 1953 conference. Finally, by extending to the Bradano Valley some of the indications already experimented before, Mazzocchi Alemanni saw the 1955 plan as the platform with which to verify and generalize some of his guiding principles. Far from revealing ideological communitarian bias, the scheme for the

\footnotetext{
${ }^{24}$ L. n. 2141 , August $9^{\text {th }}, 1951$. See [10].

${ }^{25}$ The plan (Accertamenti preliminari per un piano della Basilicata) was presented at the $\mathrm{IV}^{\text {th }}$ INU National Congress and prepared by L. Quaroni, M.L. Anversa, C. Aymonino, P. Moroni.
} 
Bradano Valley paved the way for a mature and evolved view of regional planning in which rural and urban issues coexisted with a "scientifically responsible" environmental frame.

\section{Short resume}

Filippo De Dominicis (1982, Rome), Architect, PhD in Architectural Design and Theory. Filippo studied architecture and planning in Brussels (ISACF La Cambre) and Rome (Sapienza), where he received his PhD in Architectural Design and Theory (2012). He was a post-doctoral researcher at the University IUAV of Venice (2013-2015), and an Aga Khan post-doctoral fellow at the Massachusetts Institute of Technology (2016). His research agenda deals with post-war planning experiences, with a special focus on the relationship between politics, ideologies and technocracies in the Global South.

\section{References}

1. GAROFALO, F.; VERESANI, L. 1989. "Verso una "urbanistica esatta": i quartieri del dopoguerra", in Adalberto Libera. Opera Completa, Milan, Electa: 104-120.

2. TAFURI, M. 1986. Storia dell'architettura italiana, 1944-1985, Turin, Einaudi.

3. OLMO, C. 1992. Urbanistica e Società Civile: Esperienza e conoscenza 19451960, Turin, Bollati Boringhieri.

4. MUMFORD, L. 1945. "Un'introduzione americana ad Howard”, Metron, $\mathrm{n}^{\circ}$ 1, p. 213.

5. SCRIVANO, P. 2012. Building Transatlantic Italy: Architectural Dialogues with Postwar America, Farham, Ashgate. DOI: https://doi.org/10.4324/9781315570501

6. LEVI, C. 1945. Cristo si è fermato a Eboli, Turin, Einaudi.

7. GRASSINI, P. 1952. "La dimensione umana nella trasformazione del Mezzogiorno", in INU (ed.), Esperienze Urbanistiche in Italia, Rome, Istituto Nazionale di Urbanistica: 23-60.

8. TOXEY, A.P. 2011. Materan Contradictions: Architecture, Preservation and Politics, Farnham, Ashgate. DOI: https://doi.org/10.4324/9781315594279

9. TAFURI, M. 1974. Un contributo alla comprensione storica della vicenda dei Sassi, Matera, BMG.

10. DI LENA, C. 2007. Quando l'America scoprì i Sassi: antefatto alla Legge per il Risanamento dei Sassi, Matera, Altrimedia.

11. MUSATTI, R. (1955) 2013. La via del sud, Rome, Donzelli.

12. PICCINATO, L. 1955. "Matera: i Sassi, i nuovi borghi e il Piano regolatore", Urbanistica, vol. 24, n 15-16: 142-151.

13. MAZZOCCHI ALEMANNI, N.; CALIA, E. 1950. II problema dei Sassi di Matera: relazione dattiloscritta per il Consorzio di Bonifica della Media Valle del Bradano, [Typewritten report] Matera, s.n.

14. MAZZOCCHI ALEMANNI, N. 1955. La riforma agraria, Asti, Arethusa.

15. MISIANI, S. 2017. "De la colonización interna a la reforma agraria: el intinerario de Nallo Mazzocchi Alemanni”, in S. Misiani, C.B. Gómez (eds.). Costruyendo la nación: Reforma agraria y modernización rural en la Italia del siglo XX, Zaragoza, Prensas de la Universidad de Zaragoza: 221-276. 
16. TALAMONA, M. 2001. "Dieci anni di politica dell'UNRRA-Casas: dalle case ai senzatetto ai borghi rurali nel Mezzogiorno di'Italia (1945-1955). II ruolo di Adriano Olivetti", in C. Olmo (ed.), Costruire la città dell'uomo. Adriano Olivetti e l'urbanistica, Turin, Edizioni di Comunità.

17. FABBRI, M.; MURATORE, L.; SACCO, L. et al. (eds.) 1994. Dall'Utopia alla politica. Autonomia locale e rinnovamento della politica meridionale nell'esperimento comunitario, Rome, Fondazione Adriano Olivetti.

18. Intervista a Ludovico Quaroni (2011). Rome-Ivrea, Fondazione Adriano Olivetti.

19. OLIVETTI, A. 1949. "Per le comunità rurali del Mezzogiorno", Comunità, $n^{\circ}$ 1: 5.

20. MAZZOCCHI ALEMANNI, N., s.d. Relazione al progetto di colonizzazione del demanio "Matinelle" nel comune di Irsina, Matera, Matera, Tipografica Editrice Carlo Conti.

21. MAZZOCCHI ALEMANNI, N. 1951. "Il problema dei Sassi di Matera avviato verso una definitiva soluzione", L'agricolutura italiana, $n^{\circ} 7$.

22. QUARONI, L. 1955. "Lucania", Urbanistica, vol. 24, n 15-16: 54-57.

23. MAZZOCCHI ALEMANNI, N. 1955. Consorzio di Bonifica della media valle del Bradano: Piano generale di bonifica del Comprensorio, Matera, s.n. 